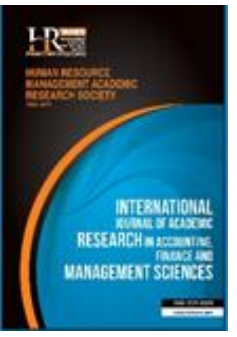

International Journal of Academic Research in Accounting, Finance and Management Sciences

Vol. 9, No. 3, July 2019, pp. 70-82

E-ISSN: 2225-8329, P-ISSN: 2308-0337

(C) 2019 HRMARS

www.hrmars.com

To cite this article: Salam, Z.A. Shourkashti, R. (2019). Capital Structure and Firm Performance in Emerging Market: An Empirical Analysis of Malaysian Companies, International Journal of Academic Research in Accounting, Finance and Management Sciences 9 (3): 70-82.

\title{
Capital Structure and Firm Performance in Emerging Market: An Empirical Analysis of Malaysian Companies
}

\author{
Zarina Abdul Salam ${ }^{1}$, Roghayeh Shourkashti ${ }^{2}$ \\ 1,2 Azman Hashim International Business School, Universiti Teknologi Malaysia \\ ${ }^{1}$ E-mail: Zarina@ibs.utm.my, ${ }^{2}$ E-mail: Shourkashti@gmail.com (Corresponding author)
}

Abstract

The aims of present study are to investigate the linear and inverted U-shaped relationship between capital structure and firm performance in the emerging market. Present study also examines the impact of financial crisis towards the relationship between capital structure and firm performance. The sample of this research is from all non-financial public listed companies in Malaysia from 2005 to 2016. This study utilized different methods such as generalized method of moment's methodology to eliminate invisible heterogeneity and endogeneity problems respectively. The results disclosed a reverse relationship between capital structure and firm's performance in Malaysian companies as emerging market and also confirm the existence of an inverted U-shaped relation between them. Additionally, the outcome of this study displays global financial crisis from 2007 to 2009 had a significant effect on the relationship between capital structure and firm performance in Malaysia as emerging market. Implications and recommendation for future research are discussed at the end of this paper.

Key words Capital structure, financial crisis, firm performance, non-linear, GMM

Received: 11 Aug $2019 \quad$ C The Authors 2019

Revised: 20 Sep 2019 Published by Human Resource Management Academic Research Society (www.hrmars.com)

Accepted: 29 Sept 2019 This article is published under the Creative Commons Attribution (CC BY 4.0) license. Anyone may reproduce, distribute, translate and create derivative works of this article (for both commercial and non-commercial purposes), subject to full attribution to the original publication and authors. The full terms of this license may be seen at: http://creativecommons.org/licences/by/4.0/legalcode

\section{Introduction}

Capital structure is defined as the company's financial structure that includes a combination of various sources of equities and debts. The influence of capital structure on firm's performance is a fundamental strategic issue of financial economists for several years. The capability of companies to fulfill the shareholders' requirements is associated with debt policy. Therefore, managers attempt to utilize the right mixture of debts and equities to hold their true cost of capital as low as possible (Abor, 2005).

Modigliani and Miller (1958), as pioneer researchers in this area found that capital structure didn't affect company's performance. Modigliani Miller (MM) theory is according to constraining presumptions of a perfect capital market, that includes exceptional features and there are no taxes, bankruptcy expenses, information asymmetries transaction expenses and agency costs of which do not match with the real-world conditions. Considering the imperfect market, some principal theories that had been proposed by other researchers as substitution to Modigliani Miller's theory are trade-off theory, pecking order theory, and agency theory.

In line with trade-off theory, companies need to trade off the expenses and benefits of liability to maximize the firm's value. The cost of liability resulted from direct and indirect bankruptcy expenses while 
benefits of debts are derived from the tax shield (Kim, 1978; Kraus and Litzenberger, 1973; Modigliani and Miller, 1963). The pecking order theory claims that in the first stage, companies utilized internal financing, followed by debts. Equity will be issued when companies were not capable of attaining more debts (Myers and Majluf, 1984; Ross, 1977). According to agency theory, managers must make an attempt to reach the optimal capital structure to maximize the firm's value which leads to reducing conflicts of interest between shareholders (Hart and Moore, 1994; Jensen and Meckling, 1976). Nonetheless, there is no comprehensive theory that can completely explain the impact of capital structure on firm's value since the real society is very intricate and differentiated (Ardalan, 2017). Capital structure decisions may influence the success rate of firm's investment. Therefore, incorrect determination of how a company finances its operation and development by consuming various sources of funds may lead to bankruptcy.

The impact of capital structure on company's performance may differ in various situations, and the result could also differ under special conditions. In other words, the new world of finance can be differentiated by operating new models, different perspectives on the current and future strategies, and new puzzle-solving. The most important goal of capital structure is minimizing the cost of financing and increasing the company's value. The capital structure model and its effect on the company's performance had been a difficult subject in accounting context and finance (Zeitun and Tian, 2007).

Capital structure is one of the most important decisions made by a company. From the technical view of capital structure, a right balance of debt and equity may affect day to day operations and future growth may have an impact on company's asset. From the tactical view, capital structure may affect the risk of gaining profit, source of funding, return of investors and lenders expectations. According to MM theory when a company decide to increase its debt, the cost of capital (WACC) increased and the company need to pay interest payment which will decline its profit and cash flow. So, high debt and high cost of financing increase the risk of default, unsuitable capital structure strategy influences the firm's health and success. Financial reports disclosed huge pool of external funds that were unnecessary which led to high cost of capital which led to bankruptcy.

The discussion over the impact of capital structure on firm performance is inconclusive regarding the empirical studies have yielded inconsistent outcomes ranging from positive to negative to no relationships at all. The study of the relationship between capital structure and firm performance have presented different results that disclose knowledge gaps and raises a substantial question about the linkage between capital structure and firm performance of firms listed at the Malaysia stock Exchange. Moreover, the concept of capital structure has been extensively studied in developing countries while there are a few studies of capital structure and firm performance in emerging market such as Malaysia, which is an exportbased country. The recession in 2007 had significantly influenced firms' performance in many industries. Malaysia's export reduced around 28 percent in January 2009 and Malaysia GDP annual growth rate also dropped that may affect manager's decisions to choose the right structure of debts and equities. The objective of this research is to identify the association among capital structure and firm's performance in a linear and inverted U-shaped approaches and also to investigate this relationship during global financial recession in 2007-2009.

\section{Literature Review}

In accordance with MM theory, in perfect market, investors will sell their stock if the company use debt because there will be less risk of highly leverage company not able to pay high return. In imperfect market, there are several theories used include pecking order theory, agency cost theory, trade off theory and market timing theory. According to pecking order theory, companies prefer internal financing and will issue debt, followed by issuing equities if they are unable to provide more debt. This theory doesn't consider an optimum debt ratio to maximize company's value (Myers and Majluf, 1984).

There are different types of agency cost theory namely agency cost of equity and agency cost of debt. These theories are related to the contrasts among shareholders, bondholders and directors. Agency cost of equity is pointed to the conflict between managers and shareholders. Managers attempt for personal goals and not concentrating on maximizing the firm's value and returns. Thus, managers in high debt companies made an effort to invest on cost-effective and profitable projects to gain profits and pay off 
their expenses. Therefore, firm's value influence by debt by decreasing agency cost concerning to managers and stockholders (Hart and Moore, 1994; Jensen, 1986).

In compliance with trade off theory, companies tend to make an optimal capital structure to maximize the firm's value. Therefore, they will trade off between debt expenditures and benefit which is related to the tax saving. As a result, company's value that utilized debt was similar to the company that didn't use debt plus tax shield after subtracting financial distress expenses (Kim, 1978).

Consistent with market timing theory, capital structure is affected by the circumstances of stock price market. In other words, managers' financing decisions depend on stock price market, so there is no concept of optimum capital structure to maximize firm performance in market timing theory. Managers may decide to select debt or issuing equity in different situation, for example, they will issue stocks when the price increase or overvalued, in order to take benefit of this conditions and utilize debt when they found a reduction of share prices (Baker and Wurgler, 2002; Kayhan and Titman, 2007; Myers and Majluf, 1984).

Lin and Chang (2011) analyzed data of 196 Taiwanese listed companies (1993-2005) and found the relationship between leverage and firm performance. When the leverage ratio is $9.86 \%$, with increasing one percent in debt, companies can achieve $0.0546 \%$ more in company's value and when debt ratio is between $9.86 \%$ and $33.33 \%$, with increasing one percent in debt, performance will increase $0.0057 \%$.

Most of capital structure theories confirm the existence of association among debt and firm's value, which had been discussed in different ways and also led to different results. Abor (2005) found a positive relationship between capital structure and profitability. This study used Ghana Stock Exchange listed companies from 1998-2002. Berger and Patti (2006) examined banking industry in U.S. and concluded that a higher debt ratio was positively related with higher firm's value because if a company increased its debt around one percent, it can get six percent more in profit. Gill, Biger, and Mathur (2011) also found the positive linkage between short-term debt and long-term debt to total assets and firm performance. Nevertheless, there are several studies that conclude a negative relationship between capital structure and firm performance in developing market countries (Abor, 2007; Harris and Raviv, 1991; Majumdar and Chhibber, 1999; Zeitun and Tian, 2007). Malaysia is a developing market, where the economy is progressing towards advanced market by the rapid growth and industrialization. Therefore most companies in Malaysia use debts for their business operations and this study hypothesized that:

\section{$H_{1}$. Capital structure influence firm performance negatively in emerging market.}

The global financial crisis in 2007 had influenced many countries in developed and emerging market such as Malaysia. Many sectors such as manufacturing and investment sectors are affected by the global financial crisis. Malaysia exports had decreased around 45\% (from RM64 billion to- RM38 billion), and this new economic condition forced managers to choose different policy in their capital structures, working capital and other financial issues. Therefore, this study attempts to examine the effect of financial crisis on capital structure and firm performance and hypothesized that:

$\mathrm{H}_{2}$. Global financial crisis affects the relationship between capital structure and firm performance in emerging market.

Several researchers have detected a non-linear linkage among capital structure and firm performance, that implies, leverage can affect firm performance positively and negatively (Berger and Patti, 2006; Margaritis and Psillaki, 2010). At the low-level, leverage help companies to increase performance by the tax shield and decreasing agency costs. Nevertheless, when a company uses more debt, it can lead to lower performance since, there is financial distress and also agency costs of debt. Therefore, current study hypothesized that: market.

$H_{3}$. There is a non-linear relationship among capital structure and firm performance in emerging

\section{Methodology of Research}

One of the most important goal of this study, is to examine the relationship between capital structure and firm performance in linear and nonlinear approaches and to identify the impact of financial 
recession on this association. Data was gathered longitudinally from a large panel of public listed nonfinancial firms in Malaysia from 2005 to 2016 (650 firms) because it includes Global recession and collapse of Wall Street in 2007-2009 that may affect Malaysia and the analysis also include the recent years. This paper utilized panel data methodology to remove unobservable heterogeneity and generalized method of moments (GMM) for problems on endogeneity.

The present study used three measures for firm performance based on accounting performance and market performance. Accounting performance includes Return on Asset (ROA) that is calculated by dividing earnings after interest and tax into total assets, and Return On Equity (ROE) that is calculated by dividing earnings after interest and tax into total equity (Jiraporn and Liu, 2008). Tobin'sQ is employed for presenting market performance that is calculated as the firm's market value to book value of debt (Driffield et al., 2006).

Capital structure can be determined in several methods which includes book value and the market value (Cespedes et al., 2010; Kayo and Kimura, 2011). This research used book value of total debts to total assets (TD/TA) and also market value of total debts to total assets (MTD/TA) as indicators of capital structure. This study used the book value of short term debt to total asset (SD/TA), book value of long term debt to total asset (LD/TA), market value of short term debt to total asset (MSD/TA) and market value of long term debt to total asset (MLD/TA) in the robustness test. Control variables include growth, tangibility, tax, risk, investment, cash flow, liquidity and size.

Panel data multiple regression analysis was performed to analyse the direction and degree of each variables' relationships. Pooled panel, Random effect (RE) and Fixed effect (FE) assessment approaches are Static Panel analysis. The linear regression may be written as follows:

yit $=\alpha+\beta x i t+$ uit

Where:

t: time and $i$ firm.

yit: regressand.

xit: $K \times 1$ vector of independent variables

$\beta: K \times 1$ vector of coefficients

uit : error term

$\alpha$ : Intercept or constant

If unseen heterogeneity is neglecting totally and the uit is related to xit, the OLS estimators are consistent and unbiased. If the unseen individual impacts (cross specific impacts) emerge, usual in non-trial study (Baltagi, 2005), RE and FE are preferred rather than OLS approach. The current study used cross error element at cross level and also disturbance is independent with both. Hence, the equation is:

$$
\text { yit }=\alpha+\beta x i t+\alpha i+\text { eit }
$$

If xit is correlated to $\alpha \mathrm{i}$, leading to the correlation between xit and uit, then the Fixed effect (FE) method would provide stable estimators whereas estimators of OLS would be inconsistent. If $\alpha i$ and xit are not correlated, estimators of OLS would be reliable but inefficient since uit is auto-correlated and heteroskedastic. To improve its efficacy, the RE is recommended.

To select the most suitable method, an F-test (Pooled OLS vs the FE), the Breusch-Pagan Lagrange Multiplier (LM) test between Pooled OLS and RE, and the Hausman test between RE and FE methods were conducted. The desirable model would be chosen based on the results.

Furthermore, to improve effectiveness, auto-correlation checking through the Wooldridge method, group-wise heteroskedasticity with the Breusch Pagan (BP) approach, and Panel Unit-root tests for checking the stationary of each variable were performed. If the model has both autocorrelation and heteroskedasticity, write method (ROBUST) will be considered in estimating the model. Furthermore, the variable should be stationary in order to be applied in each equation regression.

Even though an adjusted standard error model can remedy the heteroskedasticity and autocorrelation. Wintoki et al. (2012) have noted endogeneity bias, nevertheless, lasts in the model, since 
the RE and FE primarily restricts unobserved heterogeneity. They have no control on endogeneity by timeindependent ones, the measurement errors and inverse interconnection. Consequently, RE or FE may not be unbiased, particularly in short-run data (Cameron and Trivedi, 2005). To solve it, researchers recommended dynamic panel GMM. Though, the issue when utilizing estimators is the trouble in designating valid instruments since with fragile instruments are more probable not to be unbiased. Hence, estimation with unreliable may not be desirable. So, the study utilized GMM, Arellano and Bond (1991) to remedy the abovementioned problem. GMM offers an abundance of instruments to simplify including instruments that make it useful for a few periods and achieving the valid instruments and overcome the problem of over-identification (Roodman, 2006). Since the current study has few periods, it applied first difference and System GMM. In this case, lagged differences are considered as instruments in first difference and levels.

Arellano and Bond (1991) provided two diagnostics for the validity of the GMM: Hansen test and Sargan test (or autocorrelation test in GMM) for over-identification (Wintoki et al., 2012). Therefore, this research performed and reported the result of dynamic Panel data (GMM), since it's the best method for performing analysis.

\subsection{Empirical model}

To assess the association among company's performance and capital structure, the study applied this frame:

$F P i t=\alpha+\beta 1 C S i t+r Z i t+$ eit

Where:

$F P_{i t}$ : Firm performance (Tobin Q, ROE and ROA)

$C S_{i t}$ : Structure of capital measured by the ratios of debts over asset market and book value;

$Z_{i t}$ : control variables. predicted.

Following $\mathrm{H}_{1}$, leverage could negatively impact on DV, therefore, a negative indication of $\beta 1$ is

Additionally, testing linear relationship among company's performance and capital structure, current research applies the quadratic equation reinforced with Berger and Di Patti (2006) and also Margaritis and Psillaki (2010) to permit a non-linear function.

$$
\text { FPit }=\alpha+\beta 1 C S i t+\beta 2 C S i t 2+\gamma Z i t+\text { eit }
$$

Hypothesis $2\left(\mathrm{H}_{2}\right)$ recommended that Global Financial Crisis influence the association among capital structure and firm performance.

$$
\text { FPit }=\alpha+\beta 1 C S i t+\beta 2 D U M i t+\text { Zit }+ \text { eit }
$$

Hypothesis $3\left(\mathrm{H}_{3}\right)$ suggested the inverse U-formed association among firm value and capital structure. Especially, leverage is linked positively with value of firm; though, at a high value, the linkage shifts from direct to reverse. The acceptable range for the relationship is that $\beta 1>0$ and $\beta 2<0$.

\subsection{Findings}

The descriptive statistics summary of all variables are provided in Table 1. The average of TDTA and MTDTA overall account for 0.460 and 0.423 (2005 to 2016) and broadly dispersed, 0.003 to 232.75 and 0.001 to 1.01 .

Performance indicators were measured by ROE, ROA and Tobin $\mathrm{Q}$. The mean of returns on assets and equity are 0.04 and -0.01 . The mean of TobinQ shows 1.17 , table also shows that the range of Tobin's $Q$ differs from 0.005 to 232.75 . The other alternative showed a lower spread in their value. ROA ranged from -103.32 to 11.06 , and the ROE ranged from -21.67 to 12.73 . This suggests the significant performance gaps between Malaysian firms in this phase. 
Table 1.Descriptive statistics

\begin{tabular}{|c|c|c|c|c|c|}
\hline Variables & Observation & Mean & Std. Dev & Min & Max \\
\hline \multicolumn{6}{|c|}{ Capital Structure } \\
\hline TDTA & 7,400 & 0.460 & 3.885 & 0.003 & 232.75 \\
\hline MTDTA & 7,345 & 0.423 & 0.229 & 0.001 & 1.01 \\
\hline \multicolumn{6}{|c|}{ Firm Performance } \\
\hline ROA & 7,410 & -0.011 & 1.583 & -103.327 & 11.063 \\
\hline ROE & 7,410 & 0.042 & 0.571 & -21.674 & 12.730 \\
\hline Tobin Q & 7,355 & 1.178 & 4.728 & 0.005 & 232.75 \\
\hline \multicolumn{6}{|c|}{ Control Variables } \\
\hline TANGI & 7,368 & 0.438 & 0.457 & 0.000 & 21.509 \\
\hline GROWTH & 7,376 & 5.028 & 1.589 & -2.995 & 10.384 \\
\hline TAX & 7,383 & 0.168 & 1.848 & -67.000 & 79.000 \\
\hline RISK & 7,408 & 766.345 & 19247.78 & -0.147 & 564346.1 \\
\hline INV & 7,406 & -0.046 & 0.354 & -30.109 & 0.064 \\
\hline CASHF & 7,396 & -0.010 & 1.585 & -103.327 & 11.063 \\
\hline LIQ & 7,378 & 0.067 & 0.083 & 0.000 & 1.000 \\
\hline SIZE & 7,410 & 5.624 & 1.524 & -3.218 & 11.546 \\
\hline
\end{tabular}

\subsection{Correlation Analysis}

The correlation among variables applied in this model is provided in Table 2. It may be inferred that the correlations of debt ratios were high, especially, the correlation among MTDTA and TDTA, which is 0.084 . Hence, instead of mixing them, the study individually investigated the impact analysis to lower the collinearity problem. Other correlations were considerably small, suggesting no issue of collinearity.

Debt ratios, including MTDTA and TDTA were discovered to be reversed related to performance indicators since all coefficients were negative (except TDTA on ROE and Tobin Q) and meaningful at 5\%. Precisely, the correlations amid TDTA with ROA, ROE and Tobin Q were $-0.0642,0.014$ and 0.976 , when the values of MTDTA were $-0.055,-0.027$ and -0.027 .

Table 2. Correlation

\begin{tabular}{|c|c|c|c|c|c|c|c|c|c|c|c|c|c|c|c|c|c|c|c|c|c|c|c|}
\hline & ROA & & ROE & & TOBINS & & TDTA & & MTDTA & & TANGI & & GROWTH & & TAX & RISK & INV & & CASHF & & LIQ & & SIZE \\
\hline ROA & 1.000 & & & & & & & & & & & & & & & & & & & & & & \\
\hline ROE & -0.066 & $\cdots$ & 1.000 & & & & & & & & & & & & & & & & & & & & \\
\hline TOBINS & -0.890 & $\cdots$ & 0.001 & & 1.000 & & & & & & & & & & & & & & & & & & \\
\hline TDTA & -0.642 & $\cdots$ & 0.014 & & 0.976 & $\cdots$ & 1.000 & & & & & & & & & & & & & & & & \\
\hline MTDTA & -0.055 & $\cdots$ & -0.027 & .* & -0.027 & .. & 0.084 & $\cdots$ & 1.000 & & & & & & & & & & & & & & \\
\hline TANGI & -0.041 & $\cdots$ & -0.287 & $\cdots$ & -0.011 & & -0.023 & .. & -0.016 & & 1.000 & & & & & & & & & & & & \\
\hline GROWTH & 0.078 & $\cdots$ & 0.105 & $\cdots$ & -0.086 & $\cdots$ & -0.039 & $\cdots$ & 0.145 & $\cdots$ & 0.036 & $\cdots$ & 1.000 & & & & & & & & & & \\
\hline TAX & 0.004 & & 0.007 & & -0.004 & & -0.003 & & 0.000 & & -0.003 & & 0.022 & • & 1.000 & & & & & & & & \\
\hline RISK & 0.002 & & 0.002 & & -0.005 & & -0.003 & & -0.014 & & 0.009 & & 0.016 & & 0.000 & 1.000 & & & & & & & \\
\hline INV & 0.744 & $\cdots$ & -0.136 & $\cdots$ & -0.001 & & -0.045 & $\cdots$ & 0.065 & $\cdots$ & -0.021 & . & 0.019 & • & 0.002 & 0.003 & 1.000 & & & & & & \\
\hline CASHF & 1.000 & $\cdots$ & -0.066 & $\cdots$ & -0.890 & $\cdots$ & -0.642 & $\cdots$ & -0.056 & $\cdots$ & -0.041 & $\cdots$ & 0.078 & $\cdots$ & 0.004 & 0.002 & 0.744 & $\cdots$ & 1.000 & & & & \\
\hline LIQ & -0.066 & $\cdots$ & 0.036 & $\cdots$ & 0.150 & $\cdots$ & 0.101 & $\cdots$ & -0.184 & $\cdots$ & -0.100 & $\cdots$ & -0.019 & • & 0.005 & -0.006 & -0.024 & .. & -0.066 & $\cdots$ & 1.000 & & \\
\hline SIZE & 0.131 & $\ldots$ & 0.073 & $\cdots$ & -0.150 & ... & -0.113 & $\cdots$ & 0.117 & $\cdots$ & -0.046 & $\cdots$ & 0.837 & $\ldots$ & 0.011 & 0.014 & 0.047 & $\cdots$ & 0.131 & $\cdots$ & -0.152 & $\cdots$ & 1.000 \\
\hline
\end{tabular}




\subsection{Unit Root Test}

This study performed panel unit root tests (Augmented Dickey-Fuller and Phillips-Perron unitroot test) to check the stationary level of each variable، including dependent, independent and control variables: the z-statistic of R. D. Harris and Tzavalis (1999) and the two t-statistics of Im, Pesaran, and Shin (2003). It applied the tests to all variables، including dependent, independent and control variables for the whole sample. In all of the cases, unit root was rejected, hence, it revealed that all variables were stationary at level I(0). However, the small T sample size made these results on panel unit roots difficult to interpret.

Table 3. Unitroot test of all variables in the model

\begin{tabular}{|c|c|c|c|}
\hline & Augmented Dickey-Fuller Test & Phillips-Perron Test & panel Unit root test \\
\hline Variable & ADF Statistic & PP Statistic & Stationary \\
\hline ROA & -12.16 & -24.62 & $\mathrm{I}(0)$ \\
\hline ROE & -13.50 & -29.82 & $\mathrm{I}(0)$ \\
\hline TOBIN'S & -11.73 & -21.66 & $\mathrm{I}(0)$ \\
\hline TDTA & -7.23 & -10.74 & $\mathrm{I}(0)$ \\
\hline MTDTA & -10.60 & -24.69 & $\mathrm{I}(0)$ \\
\hline TANGI & 4.66 & -3.75 & $\mathrm{I}(0)$ \\
\hline GROWTH & -5.21 & -14.48 & $\mathrm{I}(0)$ \\
\hline TAX & -18.79 & -43.51 & $\mathrm{I}(0)$ \\
\hline RISK & -6.60 & -22.29 & $1(0)$ \\
\hline INV & -22.76 & -43.43 & $\mathrm{I}(0)$ \\
\hline CASHF & -11.91 & -24.58 & $1(0)$ \\
\hline LIQ & -6.85 & -23.77 & $\mathrm{I}(0)$ \\
\hline SIZE & 15.55 & -5.83 & $\mathrm{I}(0)$ \\
\hline
\end{tabular}

\subsection{Multicollinearity}

While multicollinearity analysis is hard to interpret only from a correlation matrix, this study considered variance inflation factors (VIF) for all independent variables applied in this study, as shown in Table 5. The VIF determination was also a method of measuring the level of collinearity between the independent and control variables in a regression analysis (Gujarati and Porter, 2009).

VIF showed how much the variance of the estimated coefficients rose over the case of no correlation between the independent variables. If no two explanatory variables were correlated, then all values of the VIFs will be 1 . If the value of VIF for one of the variables is greater than 10 , there is high collinearity in this model.

All VIF values were less than 10 , so, it was not conceivable to form the existence of significant issue of multicollinearity. That is, there were no meaningful multicollinearity issue, so no variables will be excluded from the models of this study except Cash flow variable in Model 1 that has VIF more than 10. So only the cash flow will be removed from model 1 to remedy the issue of Multicollinearity in this model. The rest of models had no issues of Multicollinearity

\subsection{GMM Estimator}

To strengthen the findings, system two-step GMM with adjusted standard error was performed to handle with the endogenous problem demonstrated in table 4 . It approved the reversed impact of structure of capital on performance that was statistically meaningful at $10 \%$ and $1 \%$, except for TDTA in the Tobin $Q$ model. That is reversed but not meaningful. The outcomes of the diagnostics were also stated. All $\operatorname{AR}(2) \mathrm{p}$-values were greater than 0.10 , that showed, no second-order serial correlation. Likewise, the results of Hansen J were disclosed in Table 5. 
Table 4. The impact of capital structure on company's performance - GMM Model

\begin{tabular}{|c|c|c|c|c|c|c|c|c|c|c|c|c|}
\hline & \multicolumn{4}{|c|}{ Dependent variable: ROA } & \multicolumn{3}{|c|}{ Dependent variable: $\mathrm{ROE}$} & \multicolumn{5}{|c|}{ Dependent variable: Tobin Q } \\
\hline & $(1)$ & & $(2)$ & & (3) & & $(4)$ & & $(5)$ & & (6) & \\
\hline \multirow[t]{2}{*}{ TDTA } & -0.2945 & $* * *$ & & & -0.1608 & $* * *$ & & & 0.4853 & & & \\
\hline & 0.0087 & & & & 0.0211 & & & & 2.2732 & & & \\
\hline \multirow[t]{2}{*}{ MTDTA } & & & -2.8442 & $*$ & & & -1.3052 & $* * *$ & & & -1.9362 & $* * *$ \\
\hline & & & 1.5525 & & & & 0.4036 & & & & 0.1895 & \\
\hline \multirow[t]{2}{*}{ TANGI } & -0.2327 & & 0.0839 & & -0.4936 & $* * *$ & -0.4712 & $*$ & 2.4864 & & -0.1115 & $* * *$ \\
\hline & 0.1640 & & 0.0974 & & 0.0435 & & 0.2415 & & 3.1426 & & 0.0389 & \\
\hline \multirow[t]{2}{*}{ GROWTH } & 0.0752 & $* * *$ & 0.0032 & & -0.3798 & $* * *$ & 0.0724 & $* * *$ & -14.6493 & $* * *$ & 0.1222 & $* * *$ \\
\hline & 0.0172 & & 0.0495 & & 0.0228 & & 0.0268 & & 2.6290 & & 0.0251 & \\
\hline \multirow[t]{2}{*}{ TAX } & 0.0004 & & -0.0023 & & 0.0044 & & -0.0004 & & 0.1388 & & -0.0010 & \\
\hline & 0.0015 & & 0.0040 & & 0.0096 & & 0.0020 & & 0.2019 & & 0.0024 & \\
\hline \multirow[t]{2}{*}{ RISK } & 0.0000 & $* *$ & -0.000001 & $* *$ & 0.000003 & $* * *$ & 0.0000 & & 0.0002 & $* * *$ & -0.000001 & $* * *$ \\
\hline & 0.0000 & & 0.0000 & & 0.0000 & & 0.0000 & & 0.0000 & & 0.0000 & \\
\hline \multirow[t]{2}{*}{ INV } & 3.2832 & $* * *$ & 0.5645 & & -0.4098 & $* *$ & -0.9723 & & 22.7098 & & -0.8845 & $* * *$ \\
\hline & 0.0072 & & 0.4717 & & 0.1877 & & 0.5938 & & 16.1813 & & 0.1979 & \\
\hline \multirow[t]{2}{*}{ CASHF } & 2.3382 & & 1.2808 & $* * *$ & 0.2939 & $* * *$ & 0.0527 & & 7.8665 & & -0.7521 & $* * *$ \\
\hline & 0.1044 & & 0.4401 & & 0.0566 & & 0.2142 & & 6.6560 & & 0.2166 & \\
\hline \multirow[t]{2}{*}{ LIQ } & -0.3152 & $* *$ & -2.0384 & $*$ & 3.3785 & $* * *$ & -0.6364 & $*$ & 114.3628 & $* * *$ & -0.3526 & \\
\hline & 0.1430 & & 1.0458 & & 0.2547 & & 0.3626 & & 21.8708 & & 0.2170 & \\
\hline \multirow[t]{2}{*}{ SIZE } & -0.0485 & $* *$ & 0.0552 & & 0.1944 & $* * *$ & -0.0189 & & 3.6272 & & -0.0661 & $*$ \\
\hline & 0.0192 & & 0.0426 & & 0.0230 & & 0.0258 & & 2.4814 & & 0.0257 & \\
\hline \multirow[t]{2}{*}{ L.ROA } & -0.0216 & & 0.2361 & & & & & & & & & \\
\hline & 0.0730 & & 0.1565 & & & & & & & & & \\
\hline \multirow[t]{2}{*}{ L.ROE } & & & & & 0.2261 & $* * *$ & -0.0128 & & & & & \\
\hline & & & & & 0.0117 & & 0.1275 & & & & & \\
\hline \multirow[t]{2}{*}{ L.TOBIN Q } & & & & & & & & & 0.0722 & $* *$ & 0.1644 & $* * *$ \\
\hline & & & & & & & & & 0.0359 & & 0.0603 & \\
\hline \multirow[t]{2}{*}{ Constant } & 0.2604 & $* * *$ & 0.8913 & $* *$ & 1.5515 & $* * *$ & 0.5034 & $* * *$ & 70.2886 & $* * *$ & 1.4688 & $* * *$ \\
\hline & 0.1001 & & 0.4394 & & 0.0795 & & 0.1824 & & 9.0048 & & 0.1040 & \\
\hline Observations & 6,560 & & 6,528 & & 6,560 & & 6,528 & & 6,500 & & 6,480 & \\
\hline Wald Chi2 & 981427.47 & & 61.030 & & 2481.560 & & 24.490 & & 3016.040 & & 522.57 & \\
\hline Prob > Chi2 & 0.000 & & 0.000 & & 0.000 & & 0.006 & & 0.000 & & 0.000 & \\
\hline $\mathrm{AR}(1)$ & 0.007 & & 0.218 & & 0.000 & & 0.031 & & 0.000 & & 0.001 & \\
\hline $\operatorname{AR}(2)$ & 0.267 & & 0.421 & & 0.778 & & 0.970 & & 0.523 & & 0.280 & \\
\hline Hansen J test & 0.996 & & 1.000 & & 0.130 & & 0.154 & & 0.531 & & 0.646 & \\
\hline
\end{tabular}

\subsection{Robustness Check}

The result of the robustness performed was reliable with the principal results of research in supporting the negative impact of the capital-structure on performance. Table 5 revealed the regression outcomes of these 12 robustness models considering SDTA, LDTA, MSDTA and MLDTA as independent variables.

This study then applied the alternative indicators of structure to confirm the original model. Shortterm and long-term debts (book and market) were considered as capital structure. In line with the main empirical outcomes, the coefficients of leverage were all reversely significant at the $1 \%$ and $5 \%$ level while applying the alternatives. Similarly, the coefficient of booked value was meaningful at the $10 \%$ and negative, correspondingly except for LDTA in ROA and Tobin $Q$ and also ROE models except in case of Tobin-Q model with STDA as IV. The results of others seemed to be robust under different calculations of structure of capital indicators.

\subsection{Dummy for Crisis in Model}

This study inspected the effect of crisis 2007-2009 as a dummy variable (DUM) in the Panel data analysis. This dummy was indicated by number one for the year of 2007 and 2009 and zero for all other years. Based on the impact of crisis on the dependent variable, it was expected that this dummy variable had a significant coefficient with a negative sign. Table 6 obviously revealed that the crisis dummy is significant and negative for all models of ROA and ROE except for case of TDTA in ROE model. However, in two equations of Tobin $Q$, this dummy variable is insignificant. 
Table 5. Robustness check for the impact of capital structure on company's performance - GMM regressions

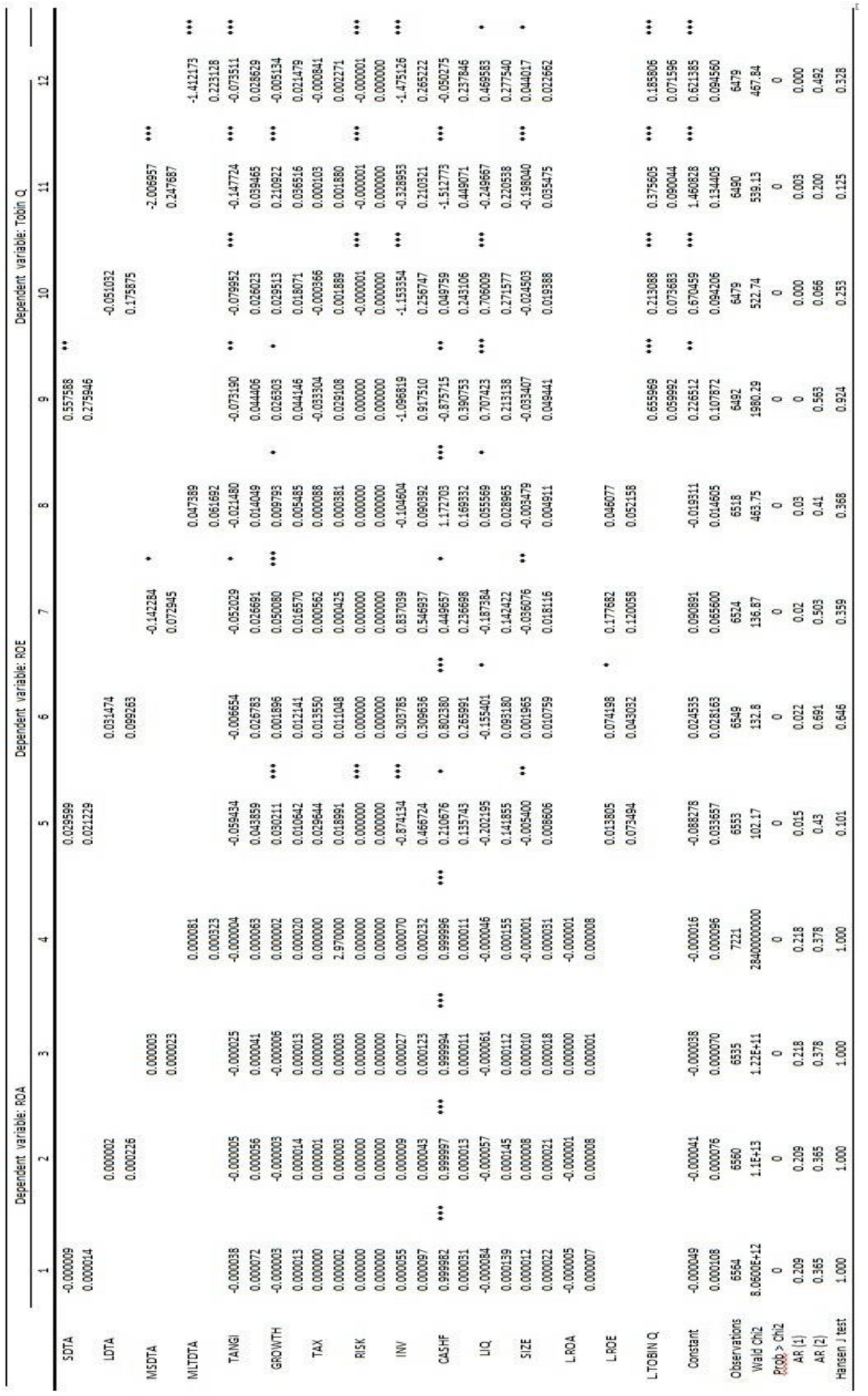


Table 6. The effect of capital structure on company's performance considering crisis - GMM Model

\begin{tabular}{|c|c|c|c|c|c|c|c|c|c|c|}
\hline & \multicolumn{3}{|c|}{ Dependent variable: ROA } & & \multicolumn{2}{|c|}{ Dependent variable: ROE } & \multicolumn{3}{|c|}{ Dependent variable: Tobin Q } & \\
\hline & $(1)$ & & $(2)$ & & (3) & $(4)$ & (5) & & $(6)$ & \\
\hline \multirow[t]{2}{*}{ TDTA } & -0.2944 & $* * *$ & & & -0.2455 & & -1.8720 & $* *$ & & \\
\hline & 0.0087 & & & & 0.0818 & & 0.8574 & & & \\
\hline \multirow[t]{2}{*}{ MTDTA } & & & -3.8545 & $* *$ & & -1.4183 & & & -0.7495 & \\
\hline & & & 1.6932 & & & 0.3989 & & & 0.8759 & \\
\hline \multirow[t]{2}{*}{ DUM } & -0.0353 & $* * *$ & -0.2533 & $* *$ & -0.0040 & 0.0781 & 0.5939 & & -0.0638 & \\
\hline & 0.0110 & & 0.1128 & & 0.0348 & 0.0270 & 0.7936 & & 0.0596 & \\
\hline \multirow[t]{2}{*}{ TANGI } & -0.2328 & & -0.2916 & & -0.4231 & -0.4821 & 1.4373 & & 0.1325 & \\
\hline & 0.1635 & & 0.1949 & & 0.2922 & 0.2521 & 3.0068 & & 0.1999 & \\
\hline \multirow[t]{2}{*}{ GROWTH } & 0.0741 & $* * *$ & 0.0872 & $*$ & -0.3497 & 0.0731 & -15.4381 & $* * *$ & 0.0094 & \\
\hline & 0.0171 & & 0.0480 & & 0.0866 & 0.0278 & 2.7158 & & 0.0584 & \\
\hline \multirow[t]{2}{*}{ TAX } & 0.0006 & & 0.0002 & & 0.0045 & 0.0003 & 0.1431 & & -0.0017 & \\
\hline & 0.0015 & & 0.0039 & & 0.0038 & 0.0020 & 0.1895 & & 0.0025 & \\
\hline \multirow[t]{2}{*}{ RISK } & 0.0000 & $* *$ & 0.0000 & $* *$ & 0.0000 & 0.0000 & 0.0002 & $* * *$ & 0.0000 & \\
\hline & 0.0000 & & 0.0000 & & 0.0000 & 0.0000 & 0.0000 & & 0.0000 & \\
\hline \multirow[t]{2}{*}{ INV } & 3.2835 & $* * *$ & 0.1285 & & 0.5313 & -0.9201 & 27.2148 & & -0.3067 & \\
\hline & 0.0076 & & 0.5858 & & 0.0730 & 0.5951 & 16.8455 & & 0.3779 & \\
\hline CASHF & OMITTED & & OMITTED & & OMITTED & OMITTED & OMITTED & & OMITTED & \\
\hline \multirow[t]{2}{*}{ LIQ } & -0.2938 & $* *$ & -2.7450 & $* *$ & 2.1720 & -0.6317 & 112.1512 & $* * *$ & 0.5017 & \\
\hline & 0.1435 & & 1.1338 & & 0.7635 & 0.3452 & 21.1732 & & 0.5845 & \\
\hline \multirow[t]{2}{*}{ SIZE } & -0.0465 & $* *$ & 0.0499 & & 0.1770 & -0.0110 & 4.7466 & $*$ & -0.0661 & \\
\hline & 0.0192 & & 0.0581 & & 0.0833 & 0.0280 & 2.7000 & & 0.0453 & \\
\hline \multirow[t]{2}{*}{ L.ROA } & -0.0235 & & 0.2087 & & & & & & & \\
\hline & 0.0733 & & 0.1331 & & & & & & & \\
\hline \multirow[t]{2}{*}{ L.ROE } & & & & & 0.2083 & -0.0131 & & & & \\
\hline & & & & & 0.0500 & 0.1212 & & & & \\
\hline \multirow{2}{*}{\multicolumn{2}{|c|}{ L.TOBIN Q }} & & & & & & 0.0663 & $*$ & 0.4461 & $* *$ \\
\hline & & & & & & & 0.0358 & & 0.2090 & \\
\hline \multirow[t]{2}{*}{ Constant } & 0.2495 & $* *$ & 1.1170 & $* *$ & 1.3973 & 0.4859 & 70.3677 & $* * *$ & 1.1371 & $* * *$ \\
\hline & 0.1001 & & 0.4939 & & 0.2606 & 0.1891 & 9.1540 & & 0.1707 & \\
\hline Observations & 6,560 & & 6,528 & & 6,560 & 6,528 & 6,500 & & 6,493 & \\
\hline Wald Chi2 & 842806.75 & & 25.4700 & & 3649.6900 & 25.96 & $3,086.48$ & & 539.29 & \\
\hline Prob > Chi2 & 0.0000 & & 0.0050 & & 0.0000 & 0.0000 & 0.0000 & & 0.0000 & \\
\hline $\mathrm{AR}(1)$ & 0.0070 & & 0.1790 & & 0.000 & 0.031 & 0.000 & & 0.0630 & \\
\hline $\operatorname{AR}(2)$ & 0.2560 & & 0.433 & & 0.833 & 0.966 & 0.467 & & 0.232 & \\
\hline Hansen J test & 0.117 & & 0.100 & & 0.500 & 0.600 & 0.766 & & 0.100 & \\
\hline
\end{tabular}

\subsection{Non-linear relationship among capital structure and performance}

In this section, analyses were performed to conclude the non-linear linkage among capital structure and company's performance. The results in Table 7 displayed a non-linear linkage emerges almost in all models but strongly in model 1 to 5 . The coefficient of the debt ratio was negatively meaningful and its square value meaningfully positive while the TDTA was independent variable, but these coefficients had reverse sings when MTDTA acts as an independent variable (IV). This revealed a reverse linkage among debt and ROA and ROE and Tobin-Q in low levels and positively related in high level in the case that TDTA acted as IV (MODEL 1 and 3 and 5). On the other hand, when MTDATA acted as an IV, both relationships in low and high level had reverse signs.

Table 7. Non-linear Model

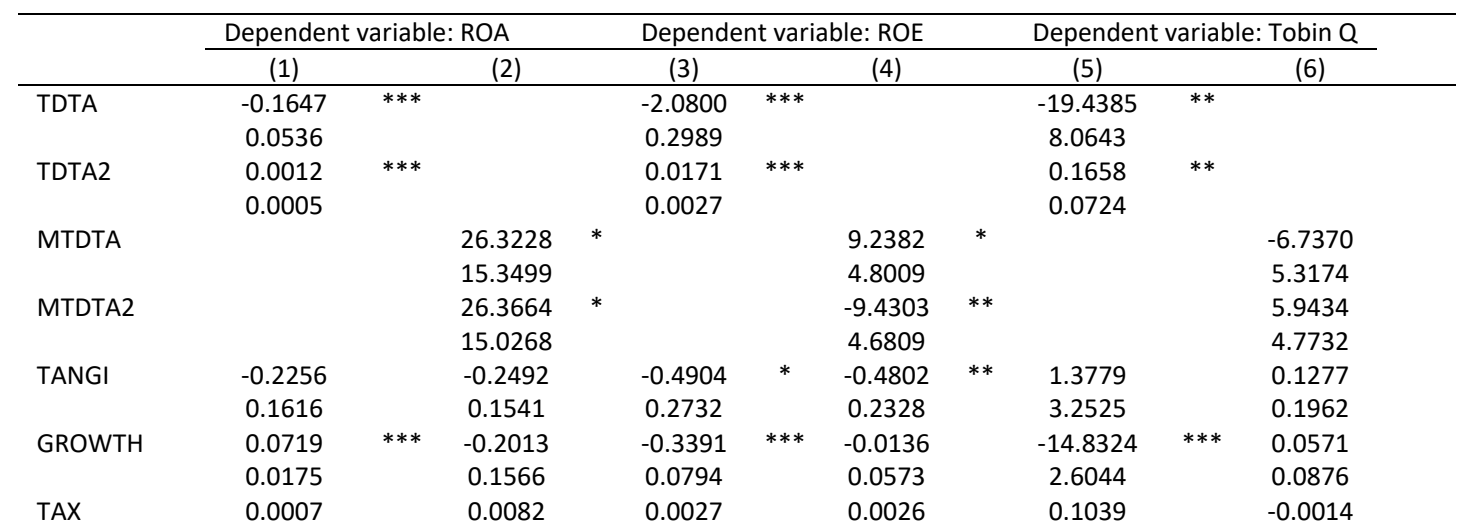




\begin{tabular}{|c|c|c|c|c|c|c|c|c|c|c|c|c|}
\hline & \multicolumn{3}{|c|}{ Dependent variable: ROA } & & \multicolumn{3}{|c|}{ Dependent variable: ROE } & \multicolumn{5}{|c|}{ Dependent variable: Tobin Q } \\
\hline & $(1)$ & & (2) & & (3) & & (4) & & (5) & & (6) & \\
\hline & 0.0014 & & 0.0082 & & 0.0038 & & 0.0036 & & 0.1762 & & 0.0032 & \\
\hline \multirow[t]{2}{*}{ RISK } & 0.0000 & & 0.0000 & & 0.0000 & $* * *$ & 0.0000 & & 0.0002 & $* * *$ & 0.0000 & \\
\hline & 0.0000 & & 0.0000 & & 0.0000 & & 0.0000 & & 0.0000 & & 0.0000 & \\
\hline \multirow[t]{2}{*}{ INV } & 3.3422 & $* * *$ & -1.4348 & & -0.3334 & ** & -1.4605 & ** & 23.7772 & & -0.2268 & \\
\hline & 0.0244 & & 0.8848 & & 0.1511 & & 0.7080 & & 16.6965 & & 0.2934 & \\
\hline \multirow[t]{2}{*}{ CASHF } & 4.2233 & & 2.4233 & & 1.6543 & & 0.5819 & & 2.4406 & & 0.1068 & \\
\hline & 0.4888 & & 0.422 & & 0.1565 & & 0.4271 & & 0.3901 & & 0.8087 & \\
\hline \multirow[t]{2}{*}{ LIQ } & -0.2538 & * & 2.2343 & & 1.7310 & $* *$ & 0.9158 & & 107.5884 & $* * *$ & -0.0047 & \\
\hline & 0.1449 & & 1.9035 & & 0.7450 & & 0.7241 & & 22.0325 & & 0.7808 & \\
\hline \multirow[t]{2}{*}{ SIZE } & -0.0492 & $* *$ & -0.0802 & & 0.1905 & ** & -0.0702 & * & 4.3192 & * & -0.0425 & \\
\hline & 0.0201 & & 0.0848 & & 0.0819 & & 0.0409 & & 2.6055 & & 0.0546 & \\
\hline \multirow[t]{2}{*}{ L.ROA } & -0.0068 & & 0.2093 & & & & & & & & & \\
\hline & 0.0809 & & 0.1386 & & & & & & & & & \\
\hline \multirow[t]{2}{*}{ L.ROE } & & & & & 0.0848 & $* * *$ & -0.0006 & & & & & \\
\hline & & & & & 0.0304 & & 0.1193 & & & & & \\
\hline \multirow[t]{2}{*}{ L.TOBIN Q } & & & & & & & & & 0.0551 & & 0.3896 & \\
\hline & & & & & & & & & 0.0352 & & 0.2742 & \\
\hline \multirow[t]{2}{*}{ Constant } & 0.2295 & $* *$ & -3.4268 & * & 2.0684 & $* * *$ & -1.0715 & & 77.3154 & $* * *$ & 1.9956 & *** \\
\hline & 0.1055 & & 2.0475 & & 0.3041 & & 0.6706 & & 10.2518 & & 0.7594 & \\
\hline Observations & 6,560 & & 6,528 & & 6,560 & & 6,528 & & 6,500 & & 6,493 & \\
\hline Wald Chi2 & 4530000.0 & & 15.2 & & 7888.6 & & 20.61 & & $3,326.07$ & & 458.230 & \\
\hline Prob > Chi2 & 0.000 & & 0 & & 0.000 & & 0.04 & & 0.000 & & 0.000 & \\
\hline AR (1) & 0.012 & & 0.136 & & 0.000 & & 0.04 & & 0.000 & & 0.137 & \\
\hline$A R(2)$ & 0.343 & & 0.413 & & 0.60 & & 0.83 & & 0.394 & & 0.294 & \\
\hline Hansen J test & 0.130 & & 0.71 & & 0.19 & & 0.10 & & 0.76 & & 0.10 & \\
\hline
\end{tabular}

\section{Conclusions}

This study represents a comprehensive study on the relationship between capital structure and firm performance from different perspectives including accounting and market based perspectives particularly in Malaysia as emerging market. Additionally, the various parts of this research examine the influence of global financial crisis during 2007-2009 on the relationship between capital structure and firm performance and also to investigate nonlinear relationship between capital structure and firm performance in Malaysia from 2005 to 2016.

Current study tried to use different proxies such as firm performance including accounting and market based proxies and also economic proxies. Present study utilized different method in comparison with previous studies. GMM model used as panel dynamic method to examine the relationship between capital structure and company's performance. As mentioned above current research used two accounting based performance measurement, including ROA, ROE and utilized Tobin'Q as the market-based performance. This study used different method for measuring capital structure include book value and market value method. The outcomes of this study provide evidence that confirms significant and negative relationships among Book value of Total debt ratio (TD/TA) and ROA, and ROE. Moreover, market values of the total debt ratio significantly and negatively affect ROA. The result of current research proved that global financial recession during 2007-2009 had a significant effect on the relationship between capital structure and firm performance. In this survey, we also investigated a nonlinear relationship between capital structure and company's performance in non-financial companies in Malaysia and found that an inverted $U$ shaped relation (positive relationship) will be appeared when the capital structure was measured by book value of TD/TA and performance was measured by ROA, ROE, Tobins' $Q$. Also, there was a nonlinear relationship between the market value of total debt's ratio and ROE.

Finally, this paper contributes to the growing literature on studies of the relationship between capital structure and firm performance from different perspectives. The outcomes of this study are not consistent with developed market that demonstrated a positive relationship between capital structure and company's performance, but is in accordance with several researchers in the context of emerging markets (Abor, 2007; Enekwe et al., 2014; Velnampy and Niresh, 2012; Zeitun and Tian, 2007). The findings of this study provide implications for firms' management where they need to find the optimal capital structure, since suitable funding strategy may affect the firms' operations and increase companies' profitability in the future. Managers that are capable of recognizing the appropriate mixture of equities, debts and optimal capital structure, can minimize cost of financing, increase return, and also decrease the agency conflicts between 
themselves and shareholders. From creditor's perspective, knowing the impact of capital structure on firm performance in emerging market helps banks to determine suitable strategies and specify the possibility of bankruptcy related to financially distressed companies. The future study is suggested to consider different measures of capital structure and firm performance to obtain more comprehensive results.

\section{References}

1. Abor, J. (2005). The effect of capital structure on profitability: an empirical analysis of listed firms in Ghana. The journal of risk finance, 6(5), 438-445.

2. Abor, J. (2007). Debt policy and performance of SMEs: Evidence from Ghanaian and South African firms. The journal of risk finance, 8(4), 364-379.

3. Ardalan, K. (2017). Capital structure theory: Reconsidered. Research in International Business and Finance, 39, 696-710.

4. Arellano, M., \& Bond, S. (1991). Some tests of specification for panel data: Monte Carlo evidence and an application to employment equations. The Review of Economic Studies, 58(2), 277-297.

5. Arellano, M., \& Bover, O. (1995). Another look at the instrumental variable estimation of errorcomponents models. Journal of econometrics, 68(1), 29-51.

6. Baker, M., \& Wurgler, J. (2002). Market timing and capital structure. The journal of finance, 57(1), 1-32.

7. Baltagi, B. H. (2005). Econometric Analysis of Panel Data (John Wiley \& Sons, New York).

8. Berger, A. N., \& Di Patti, E. B. (2006). Capital structure and firm performance: A new approach to testing agency theory and an application to the banking industry. Journal of Banking \& Finance, 30(4), 1065-1102.

9. Berger, A. N., \& Patti, E. B. (2006). Capital structure and firm performance: A new approach to testing agency theory and an application to the banking industry. Journal of Banking \& Finance, 30(4), 1065-1102.

10.Blundell, R., \& Bond, S. (2000). GMM estimation with persistent panel data: an application to production functions. Econometric reviews, 19(3), 321-340.

11.Bruslerie, H., \& Latrous, I. (2012). Ownership structure and debt leverage: Empirical test of a trade-off hypothesis on French firms. Journal of Multinational Financial Management, 22(4), 111-130.

12.Cameron, A. C., \& Trivedi, P. K. (2005). Microeconometrics: methods and applications: Cambridge university press.

13.Cespedes, J., Gonzalez, M., \& Molina, C. A. (2010). Ownership and capital structure in Latin America. Journal of Business Research, 63(3), 248-254.

14.Driffield, N., Mahambare, V., \& Pal, S. (2006). How does ownership structure affect capital structure and firm performance? Recent evidence from East Asia.

15.Enekwe, C. I., Agu, C. I., \& Eziedo, K. (2014). The effect of financial leverage on financial performance: evidence of quoted pharmaceutical companies in Nigeria. IOSR Journal of Economics and Finance, 5(3), 17-25.

16.Gill, A., Biger, N., \& Mathur, N. (2011). The effect of capital structure on profitability: Evidence from the United States. International Journal of Management, 28(4), 3.

17.Gujarati, D. N., \& Porter, D. (2009). Basic Econometrics Mc Graw-Hill International Edition.

18. Harris, \& Raviv. (1991). The theory of capital structure. The journal of finance, 46(1), 297-355.

19.Harris, R. D., \& Tzavalis, E. (1999). Inference for unit roots in dynamic panels where the time dimension is fixed. Journal of Econometrics, 91(2), 201-226.

20.Hart, O., \& Moore, J. (1994). A theory of debt based on the inalienability of human capital. The Quarterly Journal of Economics, 109(4), 841-879.

21.Im, K. S., Pesaran, M. H., \& Shin, Y. (2003). Testing for unit roots in heterogeneous panels. Journal of Econometrics, 115(1), 53-74.

22.Jensen, M. C. (1986). Agency costs of free cash flow, corporate finance, and takeovers. The American economic review, 76(2), 323-329. 
23.Jensen, M. C., \& Meckling, W. H. (1976). Theory of the firm: Managerial behavior, agency costs and ownership structure. Journal of financial economics, 3(4), 305-360.

24.Jiraporn, P., \& Liu, Y. (2008). Capital structure, staggered boards, and firm value. Financial Analysts Journal, 64(1), 49-60.

25.Kayhan, A., \& Titman, S. (2007). Firms' histories and their capital structures. Journal of financial economics, 83(1), 1-32.

26.Kayo, E. K., \& Kimura, H. (2011). Hierarchical determinants of capital structure. Journal of Banking \& Finance, 35(2), 358-371.

27.Kim, E. H. (1978). A mean-variance theory of optimal capital structure and corporate debt capacity. The journal of finance, 33(1), 45-63.

28.Kraus, A., \& Litzenberger, R. H. (1973). A state-preference model of optimal financial leverage. The journal of finance, 28(4), 911-922.

29.Lin, F.-L., \& Chang, T. (2011). Does debt affect firm value in Taiwan? A panel threshold regression analysis. Applied Economics, 43(1), 117-128.

30.Majumdar, S. K., \& Chhibber, P. (1999). Capital structure and performance: Evidence from a transition economy on an aspect of corporate governance. Public Choice, 98(3-4), 287-305.

31.Mak, Y. T., \& Kusnadi, Y. (2005). Size really matters: Further evidence on the negative relationship between board size and firm value. Pacific-Basin Finance Journal, 13(3), 301-318.

32.Margaritis, D., \& Psillaki, M. (2010). Capital structure, equity ownership and firm performance. Journal of Banking \& Finance, 34(3), 621-632.

33.Modigliani, F., \& Miller, M. H. (1958). The cost of capital, corporation finance and the theory of investment. The American economic review, 48(3), 261-297.

34.Modigliani, F., \& Miller, M. H. (1963). Corporate income taxes and the cost of capital: a correction. The American economic review, 53(3), 433-443.

35.Myers, S. C., \& Majluf, N. S. (1984). Corporate financing and investment decisions when firms have information that investors do not have. Journal of financial economics, 13(2), 187-221.

36.Roodman, D. (2006). How to do xtabond2: an introduction to 'difference'and 'system. Paper presented at the GMM in STATA', Center for Global Development Working Paper No. 103.

37.Ross, S. A. (1977). The determination of financial structure: the incentive-signalling approach. The bell journal of economics, 23-40.

38.Ruan, W., Tian, G., \& Ma, S. (2011). Managerial ownership, capital structure and firm value: Evidence from China's civilian-run firms. Australasian Accounting, Business and Finance Journal, 5(3), 73-92.

39.Velnampy, T., \& Niresh, J. A. (2012). The relationship between capital structure and profitability. Global Journal of management and business research, 12(13).

40.Wintoki, M. B., Linck, J. S., \& Netter, J. M. (2012). Endogeneity and the dynamics of internal corporate governance. Journal of financial economics, 105(3), 581-606.

41.Zeitun, R., \& Tian, G. (2007). Capital structure and corporate performance: evidence from Jordan. Account. Bus. Finance J, 1(4), 1 6-23,25,28-30,32,34-37.

42.Zou, H., \& Xiao, J. Z. (2006). The financing behaviour of listed Chinese firms. The British Accounting Review, 38(3), 239-258. 